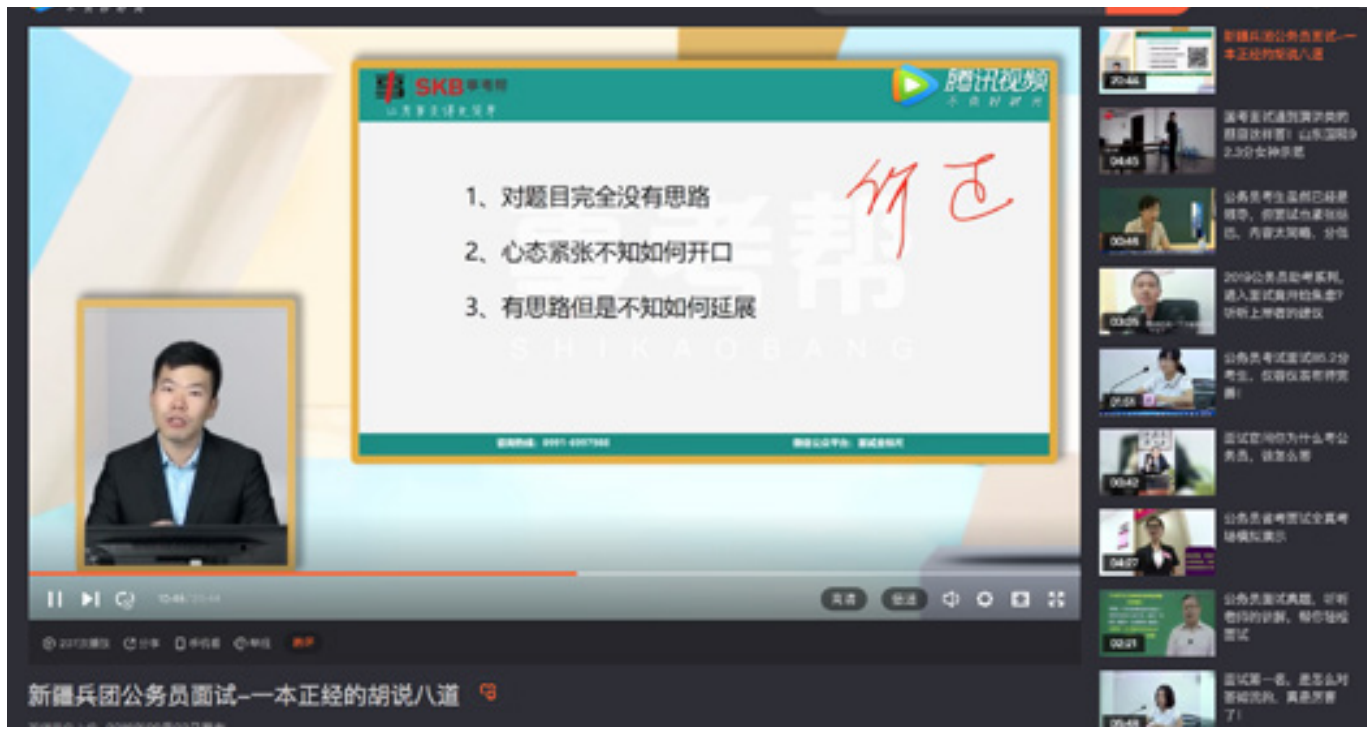

\section{Recruiting Loyal Stabilisers \\ On the Banality of Carceral Colonialism in Xinjiang}

YI Xiaocuo

The ongoing mass incarceration of Uyghurs, Kazakhs, and other Turkic Muslim people in Xinjiang is rooted in Chinese settler colonialism in the region since the 1950s via the paramilitary Xinjiang Production and Construction Corp (bingtuan) and ethnic Han influx. This article explores the ongoing human transfer project in Xinjiang through the banal language of recruitment and employment, which aims to eventually dilute and replace the native populations. While detention centres and prisons keep expanding, the bingtuan continues to legitimise itself as a stabiliser by cultivating loyalty and a sense of belonging among the new waves of Han immigrants.
A tutor training students for bingtuan interviews online.
W hile Uyghurs, Kazakhs, and other Turkic Muslims people are secretly transferred into prisons all over China (Bunin 2019; Kuo 2019; Jiang 2019), or reemerge as bare minimum wage workers on the 'reeducation camp' factory floors, China's settler institution (Byler 2019), the Xinjiang Production and Construction Corps (兵团, bingtuan), is facilitating new waves of Han influx from Inner China (内 地, neidi) to settle as farmers, civil servants, prison guards, police officers, and teachers. The totalitarian nature of such a massive human transfer is neutralised by the banal and procedural language of recruitment and employment-disguising the continued occupation and colonisation of Xinjiang. 
State-sponsored Han migration into Xinjiang has been an important element in the militarisation and securitisation of the region since the founding of the People's Republic of China (Seymour 2000; Zhu and Blachford 2015). After October 1949, demobilised People's Liberation Army soldiers were recruited into production teams to establish mechanised state farms and ranches all over Xinjiang. In 1954, bingtuan was founded. Its development needs justified its grip on the vast grasslands and waterways, as well as a huge influx of ethnic Han migrant labourers into the region. While early bingtuan work aimed at consolidating Party power among the Kazakh population along the Sino-Soviet border (Moseley 1966; McMillen 1979), today's bingtuan has expanded into a multi-billion-dollar urbanised corporation with its own jurisdiction and media that controls a majority of agricultural industries in Xinjiang (Cliff 2009).

Since Chen Quanguo-the current Party secretary of the Xinjiang Autonomous Regionestablished his carceral regime in 2017, bingtuan recruitment notices have frequently appeared on the websites of provincial governments, colleges, and universities in Inner China. With the ever-expanding detention centres and camps (Doman et al. 2018), there has been a growing need to recruit assistant police staff in Xinjiang (Zenz and Leibold 2019). Unlike civil servant recruitment materials in other provinces, bingtuan advertisements utilise propaganda discourse typically reserved for Xinjiang and Tibet, such as 'ethnic unity, national integrity and stability, anti-separatism, and illegal religious activities' to get politically obedient and manageable individuals to settle in Xinjiang (see Adv.1, Adv. 2, Adv. 3). The newly recruited-usually college graduates and underemployed youths-are thus disengaged from the consequence of their settler colonial practices. All parties involved in China's carceral colonialism in Xinjiang-bingtuan, exam tutors, universities, state media, and new settlers-engage in an Orwellian 'newspeak' that comprises thoughtless teleological Communist vocabularies of development, production, and employment. It is through such newspeak that the bingtuan legitimises itself as a perpetual settler institution in Xinjiang, and serves to cultivate colonial ideology and a sense of belonging for incoming generations of settlers.

\section{Choreographed Loyalty}

One of the major recruitment streams regards civil servant positions (公务员) for various bingtuan regiments. These advertisements are often seen on the 'career' webpages for Chinese universities (see Adv. 1 and Adv. 2). Civil servant positions are popular among college graduates in China as they offer stable income and better welfare than jobs in the private sector or selfemployment. These bingtuan recruitments are particularly systematic, targeting recruits from specific provinces or cities, aiming to ensure long-term settlements by providing attractive social benefits packages.

Different from civil servant recruitment in other provinces, these bingtuan recruitments put extra emphasis on the evaluation of the applicants' 'practical performance in safeguarding national unity, ethnic unity, and social stability' (其在维护祖国统一、维护民族 团结、维护社会稳定中的现实表现) (see Adv. 3). According to a recruitment advertisement posted in December 2018, bingtuan called for 237 civil servant applicants from Inner China provinces (excluding Tibet and Qinghai) (see Adv. 4). The recruitment targeted college graduates under 30 years old for positions at various bingtuan regiments in Southern Xinjiang, including the First Division in Aral city in Aksu, the Second Division in Tiemenguan city in Korla, and the Third Division in Tumshuk city in Kashgar. The applicants would go through interviews and background checks in Inner China cities, such as Shenyang, Zhengzhou, Changsha, and Lanzhou. The recruiting personnel would examine the applicants' eligibility, including their 'political quality’ (政治素质), ‘thought quality’(思想品 
质), 'adaptability' (适应能力), 'psychological quality' (心理素质), 'volunteering spirit' (奉献 精神), and 'discipline and law-abiding quality' (遵纪守法). The minimum service period was five years. Successful applicants would be reimbursed for their round-trip to Xinjiang.

Among the following recruitments from Gansu, Jilin, Inner Mongolia, Anhui, Hebei, and Shanxi, competition for the positions in Hotan did not even require a written exam (see Adv. 5 and Adv. 6). Successful applicants were promised a high salary, housing, official rank, and social security benefits. The state even offered to reimburse their graduate school tuition at the rate of 8,000 yuan per year (see Adv. 5, Adv. 6, Adv 7., and Adv. 8). Eligibility once again depended on political performance. Applicants had to be college graduates with a membership or preliminary membership of the Chinese Communist Party (see Adv. 5-9).

\begin{tabular}{|l|l|l|l|l|}
\hline Published date & People & From where & To where & Source \\
\hline 3 July 2017 & 113 & Sichuan province & $\begin{array}{l}\text { Various bingtuan divisions: 6th, 8th, } \\
\text { Ürümqi (i.e., Changji, Shihezi) }\end{array}$ & Adv. 17 \\
\hline 8 December 2017 & 80 & Inner China provinces & $\begin{array}{l}\text { Various bingtuan divisions: 1st, } \\
\text { 2nd, 3rd, 14th (i.e., Aksu, Bayingol, } \\
\text { Tumshuk, Hotan) }\end{array}$ & Adv. 18 \\
\hline 11 August 2018 & 694 & Inner China provinces & Various bingtuan prison systems & Adv. 19 \\
\hline 19 March 2019 & 524 & $\begin{array}{l}\text { All police school } \\
\text { graduates in China }\end{array}$ & $\begin{array}{l}\text { Various bingtuan divisions: 1st, } \\
\text { 2nd, 3rd, 14th (i.e., Aksu, Bayingol, } \\
\text { Tumshuk, Hotan) }\end{array}$ & Adv. 20 \\
\hline 15 April 2019 & 49 & Inner China provinces & $\begin{array}{l}\text { Bingtuan 2nd division } \\
\text { (i.e., Bayingol) }\end{array}$ & Adv. 21 \\
\hline 10 May 2019 & 330 & $\begin{array}{l}\text { Hebei province } \\
\text { demobilised soldiers }\end{array}$ & $\begin{array}{l}\text { Bingtuan 2nd division } \\
\text { (i.e., Bayingol) }\end{array}$ & Adv. 22 \\
\hline
\end{tabular}

Table 1: A few examples of bingtuan civil servant recruitments.

To prepare for these political performance interviews, applicants can sign up for online training courses that can be streamed on mobile phones by scanning the QR code and logging into the course's official WeChat site. The courses teach applicants to mimic the tones and gestures of Communist Party cadres during the interview. For instance, in one of these videos, a tutor teaches the applicants to perform an enthusiastic endorsement of Xi Jinping thought like an actor: 'The key is speak nonsense in a serious manner' [ 一本正
经的胡说八道] (see Adv. 12). You need to act like someone who belongs to the system. It is all about acting skills' (拼演技). Speaking to the broader audience from Inner China, this tutor is grooming politically apathetic college graduates to participate in everyday political performances of loyalty in Xinjiang, where Communist Party 'nonsense' is a serious matter.

Online tutorials also disseminate official settler colonial ideology toward Xinjiang in relation to securitisation and ethnic integration. In another video, a tutor shares 
with his viewers an actual question that was asked during a bingtuan job interview (see Adv. 13):

\section{$\mathrm{Xi}$ Jinping said: 'Make bingtuan the stabiliser of the frontier, the melting pot of different ethnic groups, and the exemplar of advanced productivity and modern culture.' Please discuss your thoughts on this quote considering the practical situation of bingtuan and explain the relationship between the three aspects.}

Fully costumed like a China Central Television anchor, the tutor gives a model answer in perfect Mandarin pronunciation:

Stabiliser, melting pot, and exemplar region are strong indications of our Party's work in land reclamation and border reinforcement, also an excellent summary of our bingtuan mission. To be the frontier stabiliser is the basic requirement for bingtuan's land reclamation and border reinforcement. Well known for its large scale, numbers, and strong ability, combining military police in battle in quelling separatist and unrest activities, bingtuan is an important force to maintain

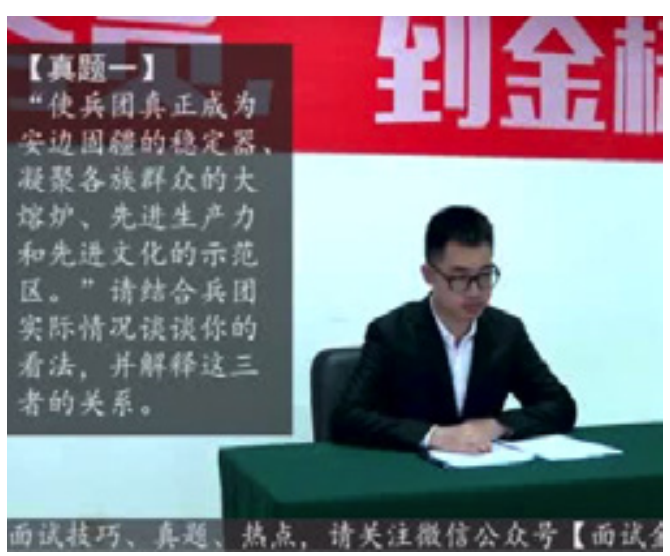

A tutor training students for bingtuan interviews online. border stability and security. Unifying different ethnic groups in a melting pot is another role bingtuan is playing. For a long time, bingtuan has implemented the Party's ethnic policy, and stressed unity, development, and prosperity of all ethnic groups, promoting harmonious living and peaceful coexistence .... In my future work, I will also practice these three points. I will lead by example by staying close to the border masses, close the gap between us, and integrate with the masses.

\section{Loyal Education and Police Spirit}

As can be seen in Table 2, prison guard positions constitute another rising employment stream into southern Xinjiang, where many 'reeducation camps' are located. Among all civil servants recruited by bingtuan in 2018, prison personnel comprised more than one third of the total prospective employees (see Adv. 14). For these positions, the 'political quality' (政 治素质) criterion was more concrete and even family members were under scrutiny. People with criminal or correctional records were not allowed to apply. If the applicants had relatives within three generations who had been sentenced to death, endangered state security, incited ethnic separatism, conducted illegal religious activity, or practiced Falun Gong, they were not eligible.

A bingtuan recruitment for 500 prison guards in 2019 did not require a written exam, only a face-to-face interview (see Adv. 15). Such exemption is rare and indicates to some degree the state's growing need for security forces in Xinjiang. In another video, a tutor introduces the eligibility requirements for the positions in the regiment's prisons, as well as which cities they are in (see Adv. 16). At minute 19:30, he casually says: 'Many of you might have looked up the specific locations of these prisons on Baidu Maps but couldn't find them. Prisons are supposed to be secretive. Of course, we can't 


\begin{tabular}{|l|l|l|l|l|}
\hline Date & People & Where from & Destination & Source \\
\hline 9 November 2018 & 111 & Anhui, Henan, Shanxi & $\begin{array}{l}\text { Regiments of the Fourteenth Division, Kunyu } \\
\text { city (Qurumqax in Hotan) }\end{array}$ & Adv. 3 \\
\hline 9 November 2018 & 61 & Hubei, Gansu & First division, Aral city, Aksu & Adv. 10 \\
\hline 9 November 2018 & 48 & Hebei, Shanxi & Second division, Tiemenguan city, Korla & Adv. 9 \\
\hline 18 December 2018 & 237 & Inner China provinces & $\begin{array}{l}\text { First, Second, Third, Fourteenth divisions, Aral, } \\
\text { Tiemenguan, Tumshuk, Qurumqax in Hotan }\end{array}$ & Adv. 4 \\
\hline 26 March 2019 & 620 & Inner China provinces & $\begin{array}{l}\text { Various bingtuan regiments and police } \\
\text { stations }\end{array}$ & Adv. 11 \\
\hline
\end{tabular}

Table 2: A few bingtuan police recruitments since 2017

mark the location of the prisons otherwise it would look like there are prisons everywhere, it's not good, right?'

It is worth mentioning that once selected for the position, prison guards must receive systematic political indoctrination as well. At the end of 2018, the bingtuan prison system initiated a series of 'Loyalty Education Programmes' (忠诚教育) to reinforce 'loyal police spirit' (忠诚警魂), which included the compulsory study of 21 essays on Xi Jinping Thought, the Communist Party Constitution, Xinjiang history, and the history of bingtuan land reclamation (Minitry of Justice of People's Republic of China 2018). The police and prison guards must study at least one hour every day and always carry the Bingtuan Prison Police 'Loyalty Education’ Study Manual (兵团监狱民警“忠城 教育”应知应会手册) with them. The employees must establish 'four kinds of consciousness' (四个意识, i.e. political consciousness, overall situation consciousness, core consciousness, and unification consciousness), regularly write reflections, participate in patriotic red song choruses, watch patriotic films, participate in 'Inheriting Red Genes, Practicing Bingtuan Spirit' (传承红色基因·践行兵团精神) speaking contests and seminars, and so on. There is a monthly examination and the ones who fail are criticised. The employees must also denounce 'two-faced people' (两面人) among themselves and participate in the 'Becoming Families' campaign（访民情、惠民生、聚民心） aimed at spying on the ethnic minority bingtuan regiments in Southern Xinjiang.

\section{(Un)transferrable Belonging: Farmers and Workers}

Another stream that absorbs a huge number of Han labourers from Inner China is the 'employment transfer' (转移就业) programme, which targets less-educated farmers and workers under 40 years old. Households of Han settlers are particularly welcome. Unlike the above-mentioned civil servant and prison guard recruitment streams that focus on political conformity and reliability, this stream's recruitment adverts clearly explain agricultural production, land area, working seasons, and annual income for the farmers, and offer full packages of social welfare that are unfathomable in the hometowns of the potential applicants.

According to a 2018 recruitment targeting farmers from Henan province, agricultural hukou (household registration) holders will be given non-agricultural hukou once they are 


\begin{tabular}{|c|c|c|c|c|c|}
\hline \multicolumn{2}{|c|}{ 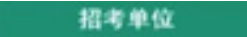 } & 招山人量 & 合it & 性男 & Iffinter \\
\hline \multirow{5}{*}{ 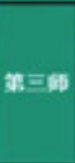 } & 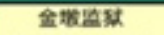 & 11 & \multirow{5}{*}{211} & 男 & \multirow{5}{*}{ 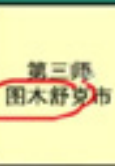 } \\
\hline & 盖米里竞監期 & 67 & & 男/女 & \\
\hline & H盖麦是盟动 & 07 & & T/t女 & \\
\hline & 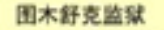 & 59 & & & \\
\hline & 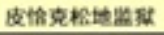 & 7 & & 男 & \\
\hline \multirow{2}{*}{ 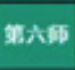 } & 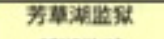 & 29 & \multirow{2}{*}{31} & 9V女 & \multirow{2}{*}{ 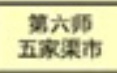 } \\
\hline & 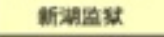 & 2 & & s & \\
\hline \multirow{3}{*}{ 28.jes } & 北拈監事 & 7 & & 男 & \multirow{3}{*}{ 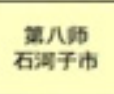 } \\
\hline & 䉼数空结 & s & 14 & m/t & \\
\hline & 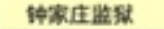 & 2 & & 男 & \\
\hline FEn & 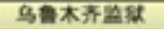 & 16 & 10 & 男 & 马霓太乔市 \\
\hline
\end{tabular}

settled in Xinjiang and their trip fares will be reimbursed (see Adv. 23). New employees are provided rent-free residence in apartments equipped with electricity and a heating system for four years. Couples can both get registered positions to grow cotton for $35 \mathrm{mu} /$ personapproximately 2.3 hectares-and are given land at the end of their first year in Xinjiang. To China's vast population of economically precarious farmers and migrant workers, social and medical insurance is one of the most attractive benefits for settling in Xinjiang. The new employees and their family members are all fully covered by health, unemployment, and retirement insurance.

Neighbouring provincial governments such as Gansu and Ningxia are collaborating with bingtuan to transfer their impoverished farmers to various regiments in Xinjiang. After a 'farewell ceremony' (欢送大会), impoverished people are finally out of sight, out of mind for the government officials. A single county in Ningxia had a quota of 900 people to be transferred to Xinjiang in 2017 (see Adv. 24). In a video recruitment advertisement for the bingtuan First Division in Aral city, Aksu, where the Han population is more than 99 percent, the narrating voice stresses that the local population is scarce and that labour input is urgent and necessary (see Adv. 25). She then lays out the recruitment plan for each regiment

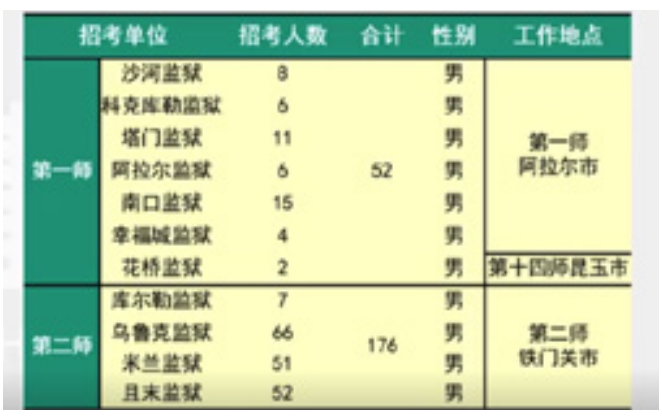

Screenshots from the bingtuan prison guard interview tutorial video, including regiment numbers, prison names, numbers of guards wanted, gender (predominantly male), and names of the cities where the prisons are located.

as part of the 13th Five-Year Plan in the region. To take a few examples from a long list: the 14th Regiment is planning to recruit 9,000 people; the 224th Regiment is planning to recruit 5,600 people; the 14th Division is planning to recruit 650 households (bingtuan recruitments favour households over individuals, as whole families are more likely to settle down), and so on.

Again, the benefits for settlers are astounding. Each individual settler will receive $20 \mathrm{mu}$ of land for each type of crop cultivated by the regiment. The settlement housing is equipped with living supplies and rent will be subsidised for the first three years. Each settler couple can earn 1,500 yuan in housing subsidies per month, including social security and hukou transferring procedures. Some regiments even provide apartments to households with six people and above. Their rent is subsidised as well and can be used for a mortgage with the aim of eventually owning the property. Settlers' children can go to the local schools without having to pay any tuition for 15 years and can enjoy added points to their college entrance examination scores (高考加分) - an affirmative action policy that has historically been directed toward Uyghurs and other ethnic minorities in Xinjiang. However, despite the all these benefits, many households are not interested in moving and, according to a report from Dingxi, Gansu (Li 2019), some poor households have 
been threatened and coerced into relocatingwith those refusing being cut off from social guarantees for impoverished families. The local government ensured relocated households do not return to Gansu by revoking their hukou and confiscating their land and houses. Villagers also revealed that in some cases the promised benefits were not realised.

Despite all this, Sina Photo painted a rosy picture of one farmer's employment transfer from Dingxi Gansu to Xinjiang, titled 'Make a Home Across 3,000 Kilometres'-an experience almost too good to be true (Sina Photo 2018) and starkly different from the stories of manipulation and coercion reported by independent sources ( $\mathrm{Li} 2019$ ).

The protagonist of Sina Photo's report is Cao Yongping. His hometown Bailu village is the poorest village in the whole province. Environmental deterioration in recent years has pushed many of his fellow villagers to go find work in the cities, and Cao himself has made a number of attempts to leave the countryside and get out of poverty. A few years ago, he took out a 100,000-yuan loan and purchased a long-haul truck to transport vegetable between Lanzhou and Chengdu. In 2016, he broke his ribs in a traffic accident and was unable to continue in the transportation business. Since then he has been in debt and has been unable to repay his loan.

In February 2017, various divisions of bingtuan started to recruit workers from Dingxi. The slogan for the recruitment was 'relocation employment in a systematic, organised, and scaled manner' (有计划、有组 织、有规模地进行转移就业). Cao learned that if he accepted to relocate to Xinjiang, he could immediately move into an apartment of 80 square metres with $70 \mathrm{mu}$ of allotted land, plus

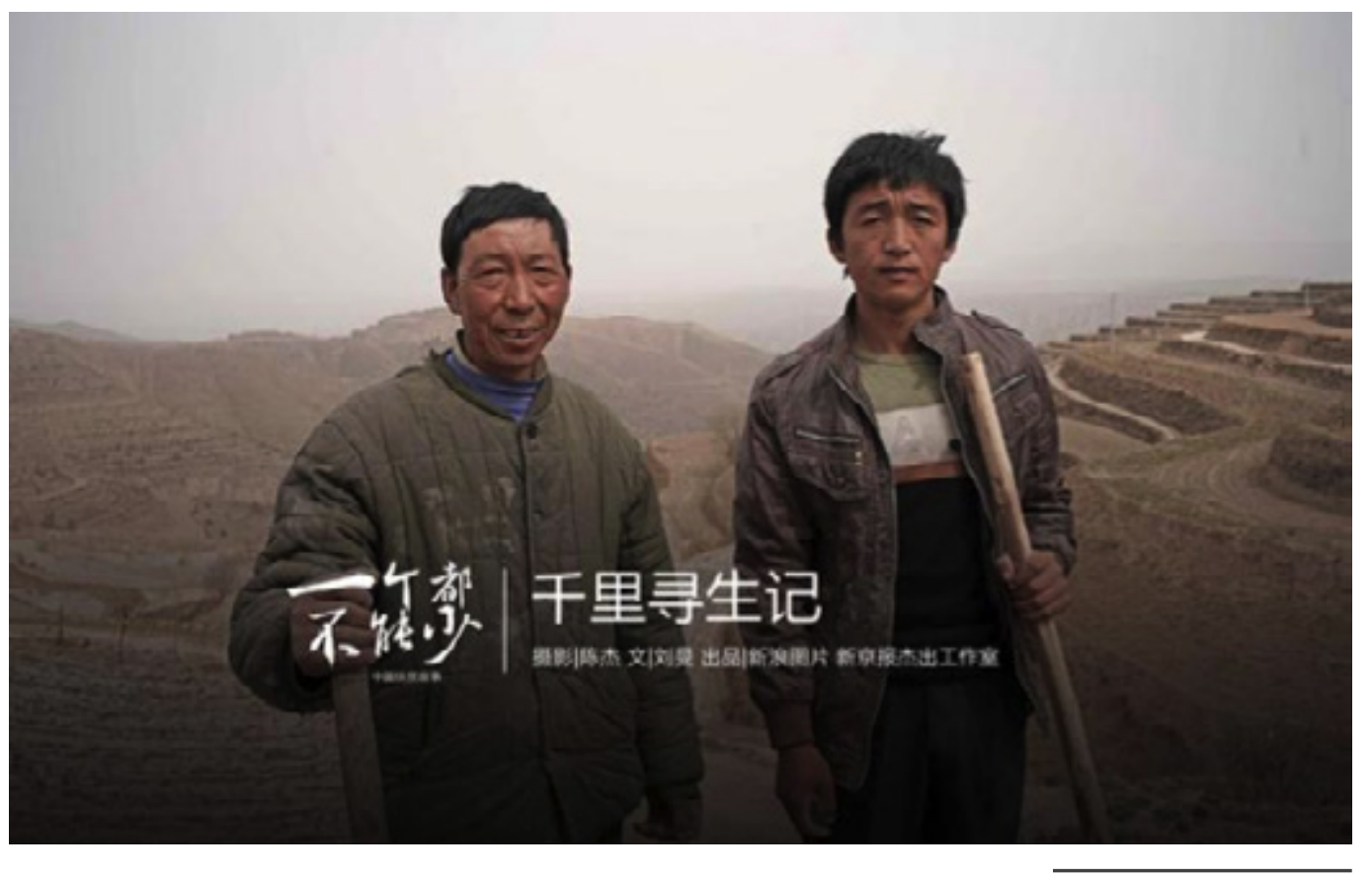

A photo from a Sina Photo report on a Gansu farmer's resettlement in Xinjiang 
15 years of free education for his children. Many farmers like Cao were recruited by bingtuan to cultivate land and settle as long-term farming employees. Cao had to learn from his father how to do agricultural work. After much preparation, Cao took his wife and children to Xinjiang first, leaving his elderly father behind to take care of the rest of the relocation work.

In 2018, Cao's family arrived in Tumshuk county on the outskirts of Kashgar, 3,100 kilometres away from his home village. They became the first household of the bingtuan 'employment transfer' programme. Unlike previous waves of migrant workers to Xinjiang, workers enrolled in this programme are required to settle down. Cao's family was arranged to settle in the Fiftieth Regiment in Tumshuk. Fellow villagers from Dingxi picked them up and registered them at the Regiment office. Cao was given the option of living in an apartment or in a one-story house with a courtyard close to his allotted land. Since he planned to bring his parents as well, he eventually chose the one-story house, with three bedrooms, a living room, and a courtyard.

In their new residence, all the life necessities and furniture were already installed. The Regiment leader told Cao that their Regiment's renovation fee was the highest among all regiments, as water, electricity, gas stove, shower, even food and cleaning supplies were all provided. Cao's family was assigned to one of dozens of houses in traditional Chinese Hui style, with an 85-square-metre courtyard, where they could live rent-free for six years. Cao thought he would have to work for more than ten years to achieve these kinds of living conditions in Dingxi. Although he worried about safety issues in Xinjiang, his fellow Dingxi compatriots told him that this place is now safer than anywhere in China. Two weeks later, Cao's parents arrived after selling their pigs back home. Cao's children have registered in local schools. A new life has begun for them.

\section{Epilogue}

Like a drop of water disappearing into a vast sea, Cao and his family faded into the state machine of human transfer in China. At the first dinner after settling down at the Regiment, Cao commented that the potatoes in Xinjiang are not as delicious as in Dingxi. Sina Photo's journalist allowed this humanistic moment of recalcitrance in Cao's story. On a broader scale, state-sponsored Han settlement in Xinjiang is normalised by this kind of triumphant narrative of poverty alleviation campaigns, burying the inconvenient truth that sees the dilution, incarceration, and replacement of native populations in Xinjiang. Cao would not be burdened by the thought of benefiting from stolen land. He has settled permanently in Xinjiang, just as countless Uyghurs and Kazakhs have been indefinitely imprisoned behind the barbed wire just a few miles away, in reeducation camps staffed by other hopeful new migrants from Inner China.

The continued challenge facing the bingtuan lies in cultivating a sense of loyalty and belonging among the newest waves of Han immigrants from Inner China, who are different from both older generations of Han settlers who arrived after 1950s and economically motivated migrant subalterns who arrived in the 1990s, such as those described by Tom Cliff (2016) in his recent ethnography of bingtuan Han settlers, Oil and Water. These new waves of incoming Han add biopolitical fuel to Chen Quanguo's carceral regime, which in return provides solid ground for the political and economic legitimacy of the bingtuan. Through the banal, Party technocratic discourses of employment and political loyalty, bingtuan fulfils the state mission of securitising Xinjiang. Yet, at the same time, it also securitises the potentially unstable situations created by the surplus of underemployed Han youths in the countryside and cities of Inner China, a problem continuously exacerbated by ongoing land dispossession and wealth disparity. 